\title{
BURSCHEL, Peter, Söldner im Nordwestdeutschland des 16. und 17. Jahrhunderts. Sozialgeschichtliche Studien
}

\section{Christophe Duhamelle}

\section{(2) OpenEdition}

\section{Journals}

Édition électronique

URL : http://journals.openedition.org/ifha/1922

DOI : 10.4000/ifha.1922

ISSN : 2198-8943

\section{Éditeur}

IFRA - Institut franco-allemand (sciences historiques et sociales)

Référence électronique

Christophe Duhamelle, «BURSCHEL, Peter, Söldner im Nordwestdeutschland des 16. und 17.

Jahrhunderts. Sozialgeschichtliche Studien », Revue de l'IFHA [En ligne], Date de recension, mis en ligne le 01 janvier 1995, consulté le 22 septembre 2020. URL : http://journals.openedition.org/ifha/1922 ;

DOI : https://doi.org/10.4000/ifha.1922

Ce document a été généré automatiquement le 22 septembre 2020.

(C)IFHA 


\title{
BURSCHEL, Peter, Söldner im Nordwestdeutschland des 16. und 17. Jahrhunderts. Sozialgeschichtliche Studien
}

\author{
Christophe Duhamelle
}

1 Mal documentée, peu étudiée, la vie des soldats de la première modernité est encore moins bien connue pour le Nord de l'Allemagne que pour le Sud. C'est donc un sujet difficile que P.B., grâce à sa connaissance de nombreux documents variés et épars, parvient à traiter avec un certain bonheur de plume.

2 L'image (aux deux sens du terme) du lansquenet puis du soldat est prise pour point de départ. Constamment négative, elle subit cependant des évolutions dont P.B. s'attache à cerner les causes. Celles-ci ne tiennent pas au recrutement, toujours lié aux réserves urbaines et rurales de pauvreté et de délinquance, mais plutôt au mode de vie des armées. Aux lansquenets hauts en couleur, participant à la codification de la discipline de leur régiment et à son application, payés en argent, mais menacés par le chômage et constituant un danger de vagabondage armé qui occupe une grande place dans les législations impériales et territoriales, se substituent en effet progressivement des soldats mieux disciplinés, que les princes, alors qu'ils construisent les premières armées permanentes, cherchent à s'attacher en réduisant leur autonomie juridique et financière (l'entretien en nature remplace en partie la solde en argent) ainsi qu'en codifiant plus précisément leur conduite et en pourchassant les soldats en rupture de ban.

3 Cette Disziplinierung reste cependant étroitement bornée, ne serait-ce que parce que les structures d'encadrement, d'intendance, ou d'accueil des soldats licenciés demeurent d'une efficacité douteuse. En outre, les candidats au métier militaire sont au XVIIe s. beaucoup plus rares, tandis que la désertion acquiert des proportions gigantesques. Les armées restent enfin marquées par la corruption, l'avidité des chefs, l'horreur des conditions de vie, et traînent toujours derrière elles la cohorte bigarrée et 
misérable des femmes, des enfants, des petits marchands et de tous ceux qui constituent le Troß.

4 En décrivant le "quotidien" des armées, P.B. restitue ainsi les lenteurs et les contradictions de l'évolution vers l'armée permanente - dont on peut regretter cependant qu'elle ne fasse pas l'objet d'une géographie et d'une chronologie plus différenciée.

5 Christophe DUHAMELLE 